\title{
Development of the "GeneSYS" database system to support trial data capture and conduct
}

\author{
D Hutton, N Smith, H Cappel-Porter, C Saw, CA Rogers ${ }^{*}$ \\ From 2nd Clinical Trials Methodology Conference: Methodology Matters \\ Edinburgh, UK. 18-19 November 2013
}

\section{Background}

Data from the recent UK-wide registration process for clinical trials units (CTU) revealed that a significant proportion of units use in-house developed solutions despite the availability of numerous commercial and open source solutions, suggesting these solutions may not meet individual trial requirements. Recognising the need to develop flexible database solutions quickly, and that are easily maintained throughout the life cycle of a study, the CTU database development team conceived and developed the "GeneSYS" database solution.

\section{Methods}

GeneSYS allows clinical trial databases to be created without any coding via an intuitive web interface. It simplifies the creation of electronic CRFs, even with complex data validation rules. The web viewer provides an easy to use interface for data collection.

\section{Results}

First released in Nov 2012, GeneSYS currently supports eight trials, including two multi-centre trials and two trials run externally to the CTU. It is hosted on a secure NHS server and accessed via the NHS clinical portal. Initial feedback has been very positive. Trial database development time has reduced significantly, thereby increasing our capacity to support more trials. We are investigating developing a mobile viewer so that electronic capture could become the primary data source.

\section{Conclusion}

GeneSYS has been a success; it has the potential to support a wider range of trials and to make database creation more efficient and intuitive enough for non-technical staff to author.

University of Bristol, Bristol, UK
Published: 29 November 2013

doi:10.1186/1745-6215-14-S1-P66

Cite this article as: Hutton et al:: Development of the "GeneSYS"

database system to support trial data capture and conduct. Trials 2013 14(Suppl 1):P66.
Submit your next manuscript to BioMed Central and take full advantage of:

- Convenient online submission

- Thorough peer review

- No space constraints or color figure charges

- Immediate publication on acceptance

- Inclusion in PubMed, CAS, Scopus and Google Scholar

- Research which is freely available for redistribution
C Biomed Central

\section{Biomed Central}

